\title{
Immunofluorescence identification of early life history stages of scallops (Pectinidae)*
}

\author{
Alain Demers ${ }^{1}$, Yvan Lagadeuc ${ }^{2}$, Julian J. Dodson ${ }^{1, * *}$, Réal Lemieux ${ }^{3}$ \\ 'Département de Biologie, Université Laval, Ste Foy, Québec, Canada G1K 7P4 \\ ${ }^{2}$ Station Marine, Université de Lille, BP 80, F-62930 Wimereux, France \\ ${ }^{3}$ Croix Rouge Canadienne, Services Transfusionnels, 2535 Boulevard Laurier, Ste Foy, Québec, Canada G1V 4 M3
}

\begin{abstract}
Species identification is the major limiting step in the study of early life history stages of bivalves. Due to the morphological similarity of veligers, sorting large numbers of plankton samples by traditional methods is a laborious and time-consuming task. The use of monoclonal antibodies and indirect immunofluorescence provides the means to rapidly discriminate among species. We describe the development of monoclonal antibodies specific to the veligers of scallop and methods to sort scallop veliger from plankton samples. Although the monoclonal antibodies were prepared against larvae of the giant scallop Placopecten magellanicus, they also recognized some adult tissues of Chlamys islandica. The monoclonal antibodies also recognized giant scallop larvae of different age groups and from different populations of the Gulf of St. Lawrence and the Canadian Atlantic Coast. The rapidity and the efficiency of this method offers the opportunity to increase the size and number of samples which is necessary when scallop veligers represent a small component of the total veliger community.
\end{abstract}

\section{INTRODUCTION}

Although most benthic marine invertebrates have a planktonic larval stage (Thorson 1946, Mieleikovsky 1971), little is known about the ecology of these early life-history stages (Cameron 1986). Consequently, the influence of the pelagic larval stage on recruitment variability is not well understood. Fine-scale spatialtemporal resolution in sampling coupled with an understanding of hydrodynamics would greatly improve our knowledge of the ecology of larvae (Boicourt 1988). However, their identification, which is traditionally based on shape and hinge structure, as well as the processing of the large numbers of samples that such sampling requires, remains a major hindrance to the study of marine invertebrate larval ecology (Lutz et al. 1982, Mann 1986, Carriker 1988).

\footnotetext{
- Contribution to the program of OPEN (Ocean Production Enhancement Network, National Center of Excellence, Natural Sciences and Engineering Research Council, Canada) and GIROQ (Groupe Interuniversitaire de Recherches Océanographiques du Québec)

- Addressee for correspondence
}

Antibody technology offers a powerful tool to study veliger populations for 2 reasons: samples can be analyzed quickly and the method makes species identification easy. Several studies have employed polyclonal antibodies to document the feeding habits of marine mammals (Pierce et al. 1990a, b), birds (Walter \& O'Neill 1985, Walter et al. 1986), insects (Boreham \& Ohiagu 1978, Crook \& Sunderland 1984, Schoof et al. 1986, Reilly \& McCarthy 1990), and marine invertebrates (Feller et al. 1979, 1985, Feller 1984, 1986, Grisley \& Boyle 1985, 1988, Taghon 1986, Theilacker et al. 1986, Gallagher et al. 1988). Antibodies have also been used in invertebrate taxonomy (Kasinathan \& Natarajan 1980, Herrera \& Cordoba 1981, Herrera et al. 1982). However, they are scarcely used in ecology even though the technology has become commonplace in many other fields (Carlson et al. 1989).

The purpose of this paper is to describe the development and use of monoclonal antibodies (mAbs) to identify the veligers of the giant scallop Placopecten magellanicus in plankton samples. Although the mAbs were prepared against $P$. magellanicus larvae, they also recognized some adult tissues of the Iceland scallop Chlamys islandica. 


\section{MATERIALS AND METHODS}

Origin of bivalve larvae. Samples of 14-d-old Placopecten magellanicus larvae were used as antigen for the preparation of monoclonal antibodies. They were sent live by air from Fisheries Resource Development Ltd (Halifax, Nova Scotia, Canada) to Québec city (Québec, Canada) in $10 \mathrm{l}$ containers. On reception, $10 \%(\mathrm{v} / \mathrm{v})$ larval suspension aliquots were placed in cryovials and kept at $-80^{\circ} \mathrm{C}$ in a solution of saline $30 \%$ and glycerol $10 \%$ (freezing solution). The parents of these larvae were collected off the Nova Scotia coast.

Other bivalve larvae were used for testing the ontogenic, population and species specificity of the mAbs. Ontogenic and population specificity tests were done on 4- and 25-d-old Placopecten magellanicus larvae obtained from Fisheries Resource Development Ltd and on scallop post-larvae from the Baie des Chaleurs (Québec). The population specificity test was also conducted on 2-d-old $P$. magellanicus larvae spawned from a female from the Baie des Chaleurs and a male from Havre St-Pierre (Québec). This last batch of larvae was obtained from the INRS Océanologie laboratory (Rimouski, Québec).

The species specificity test was made on 8-d-old Mytilus edulis larvae spawned by adults from the Baie des Chaleurs and on 7-d-old Spisula solidissima larvae spawned by adults from the Baie des Chaleurs (these two were obtained from the INRS Océanologie laboratory). Samples of bivalve veliger, collected in the Bay of Fundy (Nova Scotia) and in the Baie des Chaleurs were also used to test the antibodies species specificity. Sampling in the Bay of Fundy was carried out offshore of Hillsburn (Nova Scotia) (Fig. 1) on September 18, 1991, in accordance with the sampling of Tremblay \& Sinclair (1988). In the Baie des Chaleurs, the entire surface of the bay was sampled (Fig. 1) on August 21 and 26 and September 1, 1991.

Adult tissues of Chlamys islandica, the closest relative of the giant scallop in the Gulf of St. Lawrence, were obtained from Havre St-Pierre on the North Shore of the Gulf of St. Lawrence and used as a source of antigen for the screening of the hybridoma cultures (see monoclonal antibody preparation section). Larvae of this species were not available for testing.

Mouse immunization. Three female BALB/C mice (Charles River, St-Constant, Québec), 5- to 7-wk-old, were used for the monoclonal antibody preparation. Mice were immunized by intraperitoneal injection with $0.1 \mathrm{ml}$ of a solution made of $10 \mu \mathrm{l}$ of larvae (taken directly in cryovial) and complete Freund's adjuvant (Sigma, St. Louis, MO, USA). Three weeks later, the immunization was repeated but with incomplete Freund's adjuvant (Sigma). Seven days after the second immunization, immune response in individuals was tested with a serum sample obtained by cutting a small section of the mice tails. The $0.2 \mathrm{ml}$ of blood was allowed to clot at room temperature for $30 \mathrm{~min}$ and at $4{ }^{\circ} \mathrm{C}$ overnight. The serum was separated by centrifugation $(14000 \times g, 5 \mathrm{~min})$ and diluted (1:5) in phosphate-buffered saline solution (PBS) containing $0.01 \%$ thimerosal. The presence of antibodies was tested in

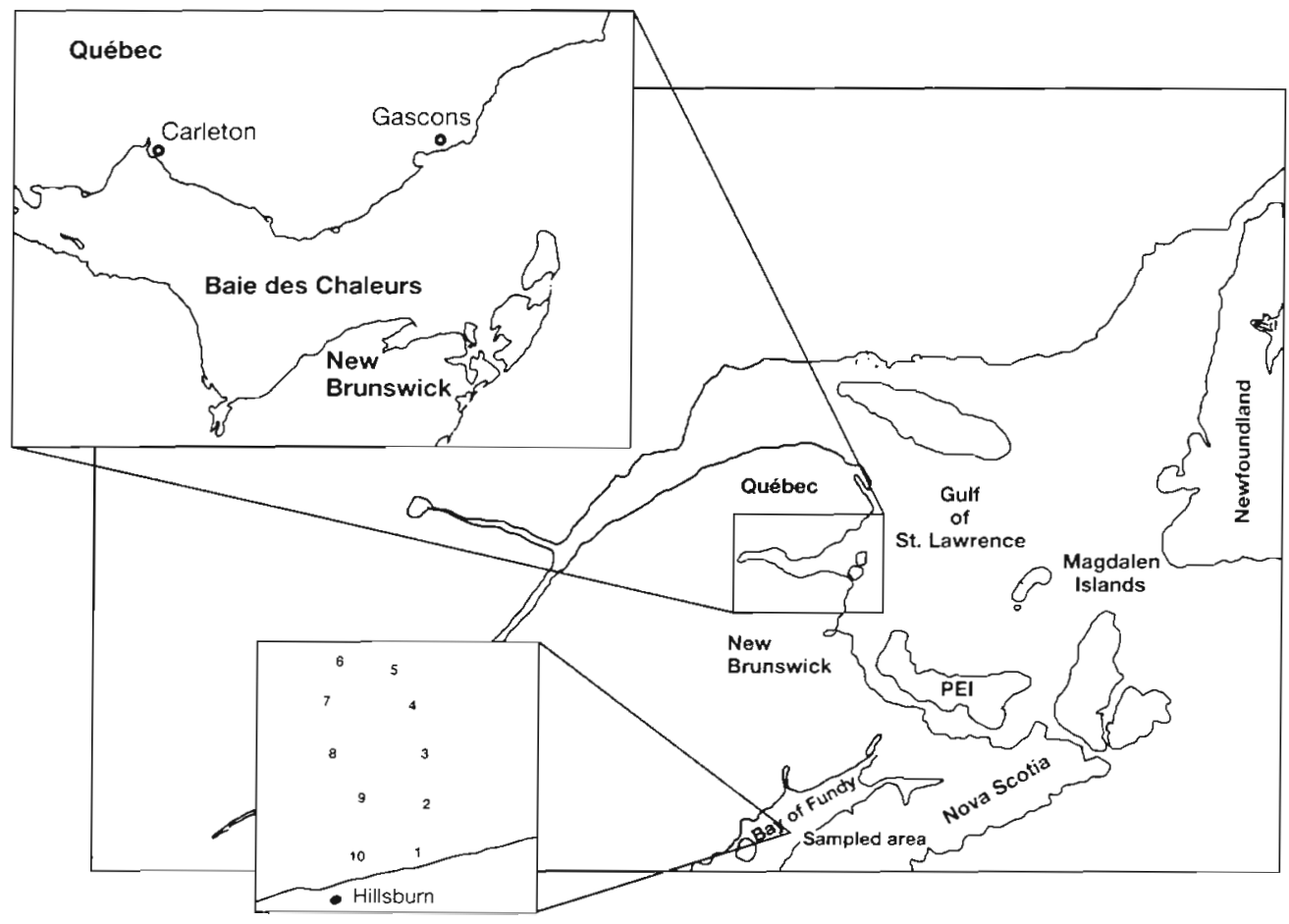

Fig. 1. Sampling sites visited in the Bay of Fundy on September 18, 1991 The entire Bate des Chaleurs was sampled (60 stations covering the bay) on August 21, 26 and September 1, 1991 
standard ELISA (described below). An intraperitoneal boost injection was performed 2 wk after the second immunization with a suspension of $10 \mu \mathrm{l}$ of larvae in $100 \mu l$ of bidistilled water. Mice were splenectomized 3 d later.

Monoclonal antibody preparation. Aseptically removed spleens were placed in a sterile sieve over a petri dish filled with $5 \mathrm{ml}$ of sterile PBS-glucose $0.2 \%$ $\left(\mathrm{w} / \mathrm{v}, 37^{\circ} \mathrm{C}\right.$ ). Spleens were then crushed with a sterile pestle and the tissue homogenized and transferred to a sterile conical $15 \mathrm{ml}$ tube. The sieve was rinsed twice with $5 \mathrm{ml}$ of PBS-glucose. Combined suspension fluids were allowed to sediment for $5 \mathrm{~min}$ and the supernatant containing splenocytes was transferred in another $15 \mathrm{ml}$ sterile conical tube. Splenocytes were centrifuged $(500 \times g, 10 \mathrm{~min})$, resuspended in PBSglucose and combined with myeloma cells (Murine SP2/O-Ag14) in a 5:1 ratio, in a final volume of $50 \mathrm{ml}$. The combined cells were centrifuged $(500 \times \mathrm{g}, 10 \mathrm{~min})$, the supernatant discarded and the cells resuspended in the remaining drops of PBS-glucose. One $\mathrm{ml}$ of a solution of PBS-glucose containing $50 \%(\mathrm{w} / \mathrm{v})$ polyethylene glycol (PEG-4000, Merck), and $2 \%$ (v/v) DMSO (dimethyl sulfoxide) was added slowly (1 $\mathrm{ml}$ for $1 \mathrm{~min}$ ) to the cell suspension with constant gentle shaking (Fazekas De St. Groth \& Scheidegger 1980). The tube was incubated at $37^{\circ} \mathrm{C}$ for $90 \mathrm{~s}$ and subsequently the volume was slowly completed to $20 \mathrm{ml}$ with PBSglucose at $37^{\circ} \mathrm{C}$ by slowly adding $1 \mathrm{ml}$ in the first $30 \mathrm{~s}$, then $3 \mathrm{ml}$ in the next $30 \mathrm{~s}$ and finally $16 \mathrm{ml}$ in the last $1 \mathrm{~min}$. The volume of the solution was completed to $50 \mathrm{ml}$ with PBS-glucose and the cells were left to rest $10 \mathrm{~min}$. The fused cells were centrifuged $(300 \times \mathrm{g}$, $10 \mathrm{~min}$ ), resuspended in Iscove's medium (Sigma), centrifuged again $(300 \times g, 10 \mathrm{~min})$ and suspended in a final concentration of $10^{6}$ cells $\mathrm{ml}^{-1}$ in Iscove's medium containing $20 \%$ Fetal Bovine Serum (FBS, HyClone Inc., Logan, UT, USA $)$, antibiotics $\left(50 \mathrm{U} \mathrm{ml}^{-1}\right.$ penicillin and $0.05 \mathrm{mg} \mathrm{ml}^{-1}$ streptomycin, Sigma), $0.1 \mathrm{mM}$ hypoxanthine, $0.4 \mu \mathrm{M}$ aminopterin and $16 \mu \mathrm{M}$ thymidine (HAT medium, Sigma). The medium was supplemented with P388D1 macrophage-derived hybridoma growth factor (IL-6) at $15 \mathrm{U} \mathrm{ml}^{-1}$ (Bazin \& Lemieux 1989). The cells were dispensed into 96-well microplates $\left(2.0 \times 10^{5}\right.$ cells well $\left.{ }^{-1}\right)$ (Costar, Cambridge, $\mathrm{MA}, \mathrm{USA}$ ) and incubated for 12 to $14 \mathrm{~d}$ at $37^{\circ} \mathrm{C}$ in humid atmosphere, $10 \% \mathrm{CO}_{2}$.

The hybridoma cells present in the antibody-positive wells (detected by ELISA) were cloned twice by limiting dilution (Harlow \& Lane 1988). The first cloning was done in Iscove's medium supplemented with $10 \%$ FBS, $1 \%$ penicillin/streptomycin, $0.1 \mathrm{mM}$ hypoxanthine and $16 \mu \mathrm{M}$ thymidine (HT medium, Sigma) and the second cloning was in Iscove, $5 \% \mathrm{FBS}, 1 \%$ penicillin/streptomycin. The cloned hybridomas were expanded to $11\left(10^{6}\right.$ cells $\left.\mathrm{ml}^{-1}\right)$ in roller cultures. Cellfree supernatants containing mAbs were supplemented with $0.05 \%$ sodium azide and stored at $4{ }^{\circ} \mathrm{C}$.

ELISA (Enzyme Linked Immunosorbent Assay). Mouse immune response and subsequent testing of hybridoma supernatants were done using an ELISA (Harlow \& Lane 1988). A coating solution was prepared by homogenizing the tissues of either adult scallops or whole larvae in $60 \mathrm{mM}$ Tris, $2 \%$ sodium dodecyl sulfate (SDS), and $100 \mathrm{mM}$ dithiothreitol (DTT) at $\mathrm{pH}$ 6.8. After a centrifugation of the homogenate $(10000 \times g, 10 \mathrm{~min})$, the protein concentration in the supernatant was determined with a Bradford test (BioRad) and aliquots of the solution were frozen at $-20^{\circ} \mathrm{C}$. Protein solutions were diluted in $100 \mathrm{mM}$ sodium carbonate/bicarbonate, $0.02 \%$ sodium azide at $\mathrm{pH} 9.7$ for coating. Microplate (96-U well plates Immulon-2, Dynatech Laboratories Inc., Alexandria, VA, USA) were coated overnight with $50 \mu \mathrm{l}$ of a 1 to $3 \mu \mathrm{g} \mathrm{m} \mathrm{m}^{-1}$ protein solution of adult scallop tissues or whole larvae. Plates were washed with saline solution $(150 \mathrm{mM}$ $\mathrm{NaCl})$ and incubated $\left(1 \mathrm{~h}, 37^{\circ} \mathrm{C}\right)$ with anti-scallop antibodies supernatant. These plates were washed again and incubated $\left(1 \mathrm{~h}, 37^{\circ} \mathrm{C}\right)$ with peroxidase conjugated goat anti-mouse IgG $(\mathrm{H}+\mathrm{L})$ antibody (Bio/Can scientific, Jackson Immuno Research Laboratories Inc., Mississauga, Ontario, Canada). The enzyme conjugate were diluted in PBS containing $0.25 \%$ casein $(\mathrm{BDH}$, Poole, Eng., Ville St-Laurent, Québec Canada) and $0.01 \%$ thimerosal. They were revealed with the orthophenylenediamine (OPD) (Abbott, Chicago, IL, USA) substrate. Optical density was read at $490 \mathrm{~nm}$. This colorimetric test revealed the presence of antiscallop mAbs.

MAbs specificity assay. The mAbs ontogenic, population and species specificity were verified on scallop adult tissues and on different species of bivalve larvae. The first method used standard ELISA using either homogenized tissues of adult scallops or homogenized larvae tissues as described in the ELISA section. The second method was an indirect immunofluorescence assay on intact larvae as described in the immunofluorescence assay section. Scanning electronic microscope photographs of hinges of bivalve larvae were obtained after the immunofluorescence staining to verify species identification.

Immunofluorescence assay. Intact frozen larvae were incubated in $100 \mathrm{mM}$ Tris, $25 \mathrm{mM}$ sodium carbonate, $25 \mathrm{mM}$ glycine, $150 \mathrm{mM} \mathrm{NaCl}$, and $0.1 \%$ formaldehyde, $\mathrm{pH} 8.6$, for $10 \mathrm{~min}$ and washed 3 times with formaldehyde-free buffer. The larvae were incubated $1 \mathrm{~h}$ with hybridoma supernatant and washed. Finally, they were incubated in the presence of fluorescein isothiocyanate (FITC)-conjugated goat anti-mouse IgG $(\mathrm{H}+\mathrm{L})$ antibodies (Bio/Can Scientific, Jackson Immuno Research 
Laboratories Inc.) diluted $1 / 75$ in formaldehyde-free buffer for $1 \mathrm{~h}$ and washed again. Fluorescent larvae were counted using an epifluorescence microscope (filter \#10, Zeiss, model Axioskop-20).

Scanning electron microscopy (SEM). Larvae were sorted under the epifluorescence microscope and the tissues of selected larvae were dissolved in commercial hypochloride solution (Javex) for $1 \mathrm{~h}$. The remaining shells were washed 3 times with water and air-dried in a petri dish. They were then taken one by one under binocular and glued with double-sided tape on SEM studs. A drop of water was put on the tape to facilitate the shell manipulation. The samples were dried and covered with a $40 \mathrm{~nm}$ layer of gold-palladium. They were observed and photographed on a JSM-840A (Jeol) scanning electronic microscope.

Bivalve sampling. The water column was sampled in the Bay of Fundy and in the Baie des Chaleurs using a $50 \mathrm{~cm}$ diameter net fitted with a $50 \mu \mathrm{m}$ mesh. Plankton samples were centrifuged twice at $500 \times g$ in LUDOX (Dupont) for $2 \mathrm{~min}$ to separate bivalve larvae from the rest of the plankton (Tremblay \& Meade 1987). After each centrifugation, bivalves were collected at the bottom of the tubes with a pipette. This technique allowed practically a $100 \%$ recuperation of the bivalve larvae. Settled bivalves were washed twice with filtered sea water to eliminate LUDOX and were subsequently frozen in liquid nitrogen. This processing, which can be done directly on a boat, took approximately $15 \mathrm{~min}$ per sample.

\section{RESULTS AND DISCUSSION}

The selection of the mAbs was done in a 3-step procedure. The screening of the fusion plates with an ELISA test allowed an initial selection of 113 hybridoma culture wells containing antibodies reactive with Placopecten magellanicus larvae tissues. Secondly, selection of antibodies was made in this pool of 113 based on the results of the ELISA test against Chlamys islandica antigen. The 12 supernatants which presented a minimum of cross-reactivity with the different adult tissues of $C$. islandica were chosen. Adult tissues were used instead of larvae tissues because pure stock of this species larvae were not available. The hybridoma cells present in the antibody-positive wells were cloned by limiting dilution culture and mAb-secreting hybridoma cell lines were established. The $12 \mathrm{mAbs}$, raised against $P$. magellanicus larvae, did not cross-react with male and female gonad tissues and mantle tissues of $C$. islandica but they recognized adult gill tissues. A third selection was completed with immunofluorescence specificity testing on the natural samples of the 2 bays. Nine of the 12 antibodies were found to crossreact with one or more species of bivalve larvae (Anomia aculeata, one species of Cardiidae and one species of Mytilidae other than Mytilus edulis). Three mAbs of the initial pool of 113 were found to be specific to the 2 scallop species. The finding that all $\mathrm{mAbs}$ prepared against $P$. magellanicus reacted to some extent with other bivalve species and also with $C$. islandica indicates that the frequency of $P$. magellanicus specific antibody is low. However, it is probable that specific antibodies could be isolated if a higher number of positive wells are tested in additional fusion experiments. Finally bivalves were consistently negative for fluorescence when incubated with non-Pectinidae specific immunoglobulin followed by FITC-conjugated goat antimouse antibody or when incubated with FITCconjugated goat anti-mouse antibody alone indicating that the assay was specific for the scallop antibodies.

Since the totality of the scallop veligers is stained in natural samples with the immunofluorescence test, we conclude that the mAbs do not distinguish the 2 species of scallop larvae as the 2 species occur in the Baie des Chaleurs, and because Chlamys islandica adult gill tissues are detected in ELISA.

The $3 \mathrm{mAbs}$ were pooled and used in subsequent immunofluorescence assays. The use of a pool of antibodies (oligoclonal) instead of one is advantageous as it avoids the possibility that an epitope is somehow modified or absent. In this hypothetical case, the use of one mAb may lead to an underestimation of the targeted species. Nevertheless, an oligoclonal solution still provides the possibility of manipulating the antibodies one by one.

None of the 3 selected mAbs cross-reacted in EIJISA or in immunofluorescence with Mytilus edulis and Spisula solidissima larvae. The immunofluorescence test on natural samples from the Bay of Fundy and the Baie des Chaleurs was repeated 3 times to ensure the validity of the results. To verify the specificity of the immuno-identification, the stained as well as the nonstained larvae were sorted and identified using SEM photos of the bivalve hinges. The selected mAbs also showed no cross-reactivity with post larvae of Hiatella artica (Fig. 2).

The pooled mabs successfully recognized 4 early stages of giant scallop development $(4-,, 14-, 25$-d-old larvae and newly settled post-larvae). Different sizes of scallop larvae (90 to $210 \mu \mathrm{m}$ ) were also recognized in the natural samples of the 2 bays. However, the different age groups of larvae showed different coloration patterns for one of the $3 \mathrm{mAbs}$. This probably indicates changes in the antigen expression during larval development as previously reported for insects and sea urchins (Westin 1972, Boreham \& Ohiagu 1978, Wang et al. 1992) 
Finally, the pooled mAbs successfully recognized giant scallop larvae from 3 populations (Nova Scotia Atlantic coast, the Bay of Fundy and the Baie des Chaleurs) as well as larvae spawned by a female from the Baie des Chaleurs and a male from Havre StPierre.

During the manipulation, the shells protected the larvae's tissues and were not an obstacle to staining. Staining problems were initially anticipated because of
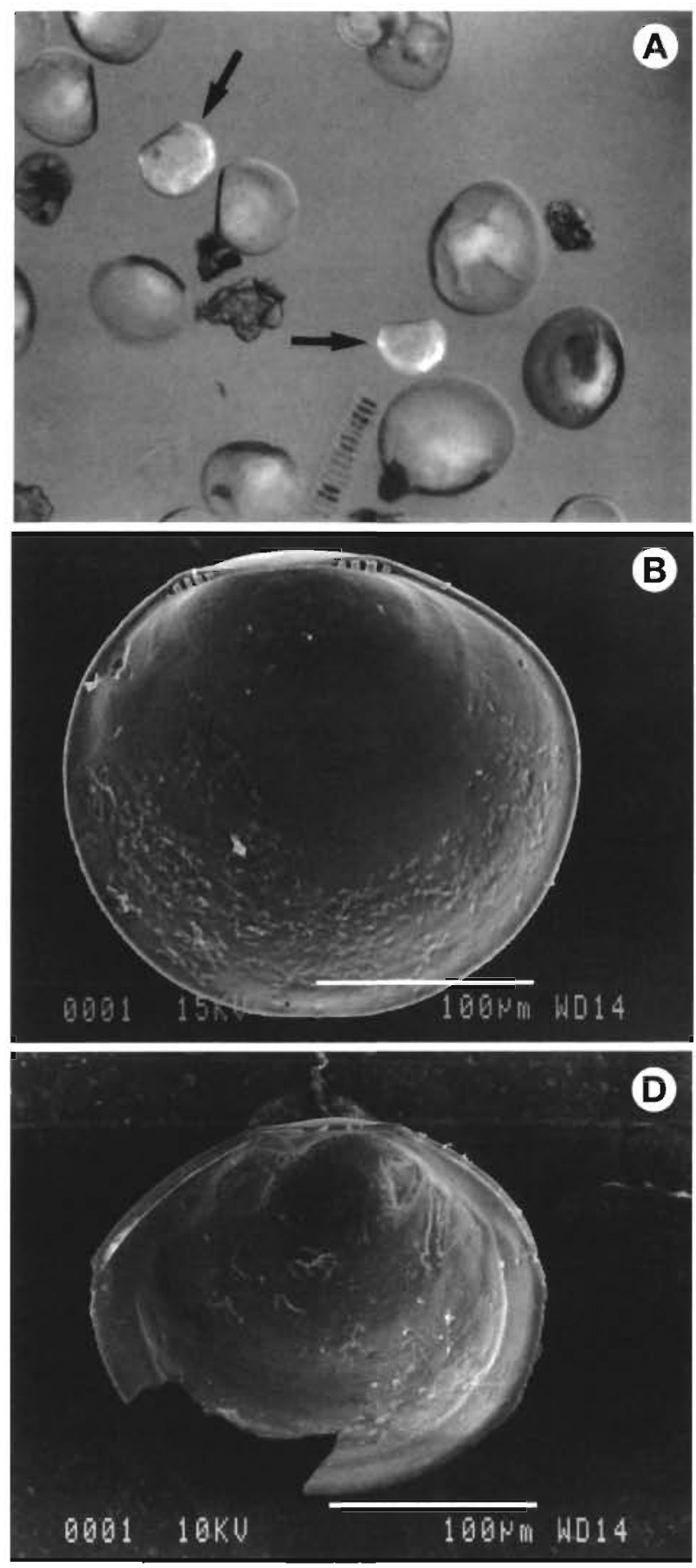

the possibility of closed shells, but this situation never occurred. However, staining intensities varied among scallop larvae for a given assay. This may indicate differential degradation of antigenic structures following transport and conservation. It may also reflect the state of the physical condition of the larvae.

In 1991, Placopecten magellanicus spawning occurred between mid-August and mid-September in the Baie des Chaleurs (M. Claereboudt pers. comm.).

Fig 2. (A) Fluorescent scallop veligers (arrows indicate fluorescing larvae) in a plankton sample. This picture was taken with a mix of transmitted and epifluorescence light. (B) Scanning Electron Microscopy picture (SEM) of scallop larva. (C) SEM of Anomia aculeata larva. (D) SEM of Cardiidae larva. (E) SEM of Mytilidae larva. Photographs $C, D$ and $E$ represent larvae which were not recognized by the pool of 3 scallop-specific mAbs but which were recognized by other antibodies
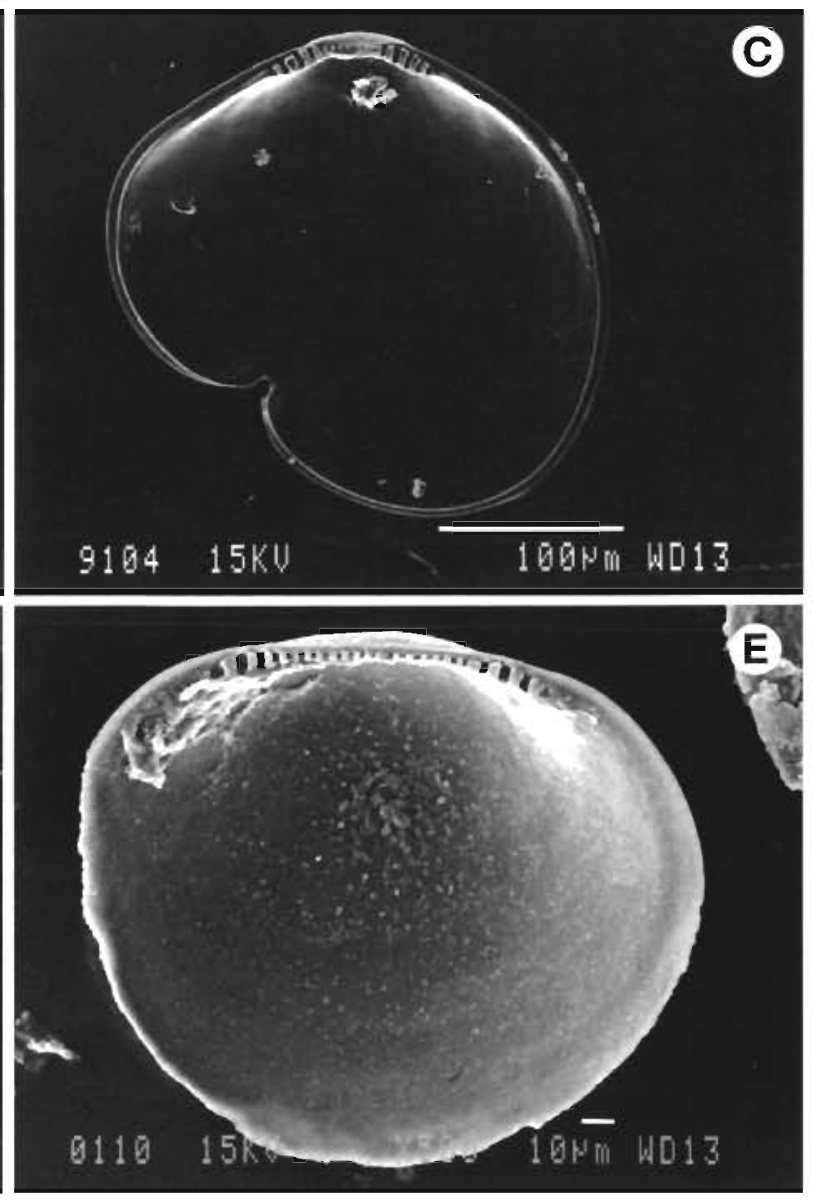
Even though the first sampling was done only a few days following the peak of spawning, no scallop larvae were found. During subsequent cruises, although large numbers of bivalve larvae were found, the quantity of scallop larvae never exceeded $0.5 \mathrm{~m}^{-3}$. In the Bay of Fundy, the number of scallop larvae per $\mathrm{m}^{3}$ varied from 3 to 116 with an average of $67(n=7, S D=42)$. The densities are comparable to those measured by Tremblay \& Sinclair (1988) which varied from approximately 3 to $180 \mathrm{~m}^{-3}$ on September 9, 11 and 13, 1984.

As mentioned previously, the major obstacle to the ecological study of the early life-history stages of bivalve larvae is the time required to identify veligers in large numbers of plankton samples. However, the ease and rapidity of the immunofluorescence technique greatly reduces sample processing time which permits an increase in the number or size of samples analyzed. In this way.the spatial-temporal resolution and precision of abundance estimates are enhanced. It took approximately $8 \mathrm{~h}$ to quantify the density of scallop larvae in 60 samples of veligers prepared onboard from plankton samples. The technique may be conducted by assistants who have no expertise in the identification of bivalve larvae.

In conclusion, the problem of species identification of veligers in the large numbers of samples generated by high-resolution spatial-temporal studies of larval distribution and survival can be largely resolved due to the time saved in employing the immunofluorescence technique for species-specific identification. The significant reduction in sample processing time permits more detailed distribution studies of economically important species even though they may occur at very low densities in the plankton.

A certain amount of the mAbs supernatants is available to readers and can be obtained from Dr Réal Lemieux (address on title page). Approximately $200 \mu 1$ are needed for each sample tested.

Acknowledgements. We sincerely thank Sonia Néron and Mark St-Laurent from the Canadian Red Cross society and Bob St-Laurent from Laval University for their generous help in the preparation of mAbs and the manuscript. We also thank Dr M. Le Pennec (Université de Bretagne Occidentale), Michel Boulé, Michel Claereboudt, Stefan Ochman and Jean Côté for assistance and GIROQ for logistic support. Research funding was provided by Ocean Production Enhancement Network (National Centers of Excellence, NSERC, Ottawa).

\section{LITERATURE CITED}

Bazin, R., Lemieux, R. (1989). Increased proportion of B cell hybridomas secreting monoclonal antibodies of desired specificity in cultures containing macrophage-derived hybridoma growth factor (IL-6). J. Immunol. Meth. 116: $245-249$

Boicourt, W. C. (1988). Recruitment dependence on planktonic transport in coastal water. In: Rothschild, B. J. (ed.)
Toward a theory on biological-physical interactions in the world ocean. Kluwer Academic Publishers, Kingston, p. 183-202

Boreham, P., Ohiagu, C. (1978). The use of serology in evaluating invertebrate prey-predator relationships: a review. Bull. entomol. Res. 68: 171-194

Cameron, R. A. (1986). Introduction to the invertebrate larval biology workshop: a brief background. Bull. mar. Sci. $39(2): 145-161$

Carlson, R., Glad, C., Borrebaeck, C. K. A. (1989). Monoclonal antibodies into the '90s: the all-purpose tool. BioTechnol. $7(6): 566-573$

Carriker, M. R. (1988). Bivalve larval research, in transition: a commentary. J. Shellfish Res. 7(1): 1-6

Crook, N. E., Sunderland, K. D. (1984). Detection of aphid remains in predatory insects and spiders by ELISA. Ann. appl. Biol. 105: 413--422

Fazekas De St. Groth, S., Scheidegger, S. (1980). Production of monoclonal antibodies: strategy and tactics. J. Immunol. Meth. 35: 1

Feller, R. J. (1984). Dietary immunoassay of Ilyanassa obso. leta, the eastern mud snail. Biol. Bull. 166(1): 96-102

Feller, R. J. (1986). Immunological detection of Mercenaria mercenaria in a predator and preparation of size-class specific antibodies. Veliger 28(4): 341-347

Feller, R. J., Thaghon, G., Gallagher, E., Keny, G., Jumars, P. (1979). Immunological methods for food web analysis in a soft-bottom benthic community. Mar. Biol. 54:61-74

Feller, R. J., Zagursky, G., Day, E. (1985). Deep-sea food web analysis using cross-reacting antisera. Deep Sea Res. 32(4A): $485-497$

Gallagher, E., Jumars, P., Taghon, G. (1988). The production of monospecific antisera to soft-bottom benthic taxa. In: Yentsch, C. M., Mague, F. C., Horan, P. K. (eds.) Lecture notes of coastal and estuarine studies. Springer-Verlag, New York, p. 74-98

Grisley, M. S., Boyle, P. R. (1985). A new application of serological techniques to gut content analysis. J. exp. mar. Biol. Ecol. 90(1): 1-9

Grisley, M. S., Boyle, P. R. (1988). Recognition of food in octopus digestive tract. J. exp. mar. Biol. Ecol. 118(1): 7-32

Harlow, E., Lane, D. (1988). Antibodies: a laboratory manual. Cold Spring Harbor Laboratory, Cold Spring Harbor, NY

Herrera, E. M., Cordoba, F. (1981). Identificación y clasificación inmunoquimica de bivalvos (almejas). Inf. Gen. Labores Cent. Invest. Biol. Baja Calif 1981: 321-331

Herrera, E. M., Sierra, A., Cordoba, F. (1982). Identificación y clasificación inmunoquimica de diferentes especies de bivalvos (almejas). Cibcasio Trans. 6: 98-109

Kasinathan, R., Natarajan, R. (1980). Electrophoretic and immunotaxonomic studies of three species of marine gastropods from Portonovo coast with reference to population management. J. Indian Fish. Ass. 10-11: 25-30

Lutz, R., Goodsell, J., Castagna, M., Chapman, S., Newell, C., Hidu, H., Mann, R., Jablonski, D., Kennedy, V., Siddall, S., Golberg, R, Beattie, H., Falmagne, C., Chestnut, A., Partridge, A. (1982). Preliminary observations on the usefulness of hinge structures for identification of bivalve larvae. J. Shellfish Res. 2(1): $65-70$

Mann, R. (1986). Sampling of bivalve larvae. In: Jamieson, G. S., Bourne, N. (eds.) North Pacific workshop on stock assessment and management of invertebrates. Can. Spec. Publ. Fish. Aquat. Sci. 92: 107-116

Mieleikovsky, S. A. (1971). Types of larval development in marine bottom invertebrates, their distribution and ecological significance: a re-evaluation. Mar. Biol. 10: $193-213$ 
Pierce, G., Boyle, P., Diack, J., Claek, I. (1990a). Sandeels in the diets of seals: application of novel and conventional methods of analysis to faeces from seals in the Moray Firth area of Scotland. J. mar. biol. A.ss. U.K. 70(4): 829-840

Pierce, G. J., Diack, J. S. W., Boyle, P. R. (1990b). Application of serological methods to identification of fish prey in diets of seals and dolphins. J. exp. mar. Biol. Ecol. 137(2): $123-140$

Reilly, P., McCarthy, T K. (1990). Observation on the natural diet of Cymatia bonsdorfi (C. Shlb.) (Heteroptera: Corixidae): an immunological analysis. Hydrobiol. 196(2): $159-166$

Schoof, D. D., Palchick, S., Tempelis, C. H. (1986). Evaluation of predator-prey relationships using an enzyme immunoassay. Ann. entomol. Soc. Am. 79: 91-95

Taghon, G. (1986). Enzyme immunoassay: a possible biochemical tool for studying feeding energetics of benthic deposit feeders. In: Thompson, M., Sarojini R., Nagabhushanam, R. (eds.) Biology of benthic marine organisms: techniques and methods applied to the Indian Ocean, Vol. 12, Indian Ed. Ser. Ashgate Publ. Co., Brookfield, VT, p. $177-184$

Theilacker, G. H., Kimball, A. S., Trimmer, J. S. (1986). Use of an ELISPOT immunoassay to detect euphausiid predation

This article was submitted to the editor on larval anchovy. Mar. Ecol. Prog. Ser. 30: 1.27-131

Thorson, G. (1946). Reproductive and larval development of Danish marine bottom invertebrates. Medd. Komm. Hovundersog. Kbh., Ser. Plankton 4(1): 523

Tremblay, M.J., Meade, L. D. (1987). Identification of planktonic sea scallop larvae (Placopecten magellanicus) (Gmelin). Can. J. Fish. Aquat. Sci. 44: 1361-1366

Tremblay, M. J., Sinclair, M. (1988). The vertical and horizontal distribution of sea scallop (Placopecten magellanicus) larvae in the Bay of Fundy in 1984 and 1985. J. Northw. Atl. Fish. Sci. 8: 43-53

Walter, C. B., O'Neill, E. (1985). Immunology as a tool in the study of competition for food between seabirds. S. Afr. J. Sci./S. A.fr. Tydskr. Wet. 81 (11): 693

Walter, C. B., O'Neill, E., Kirby, R. (1986). 'ELISA' as an aid in the identification of fish and molluscan prey of birds in marine ecosystems. J. Exp. mar. Biol. Ecol. 96(1): 97-102

Wang, L., Feng, Y., Denburg, J. L. (1992). A multifunctional cell surface developmental stage-specific antigen in the cockroach embryo: involvement in pathfinding by CNS pioneer axons. J. Cell. Biol. 118(1): 163-176

Westin, M. (1972). The occurrence of stage specific antigens during early sea urchin development. J. exp. Zool. 179: $207-214$

Manuscript first received: May 15, 1992

Revised version accepted: April 20, 1993 